\title{
Effect of Intercritical Deformation on Bainite Formation in Al-containing TRIP Steel
}

\author{
Haiwen LUO, Lie ZHAO, Suzelotte O. KRUIJVER, Jilt SIETSMA ${ }^{1)}$ and Sybrand van der ZWAAG ${ }^{21}$ \\ Netherlands Institute for Metals Research, 2628 AL Delft, the Netherlands. \\ 1) Laboratory for Materials Science, Delft University of Technology, 2628 AL Delft, the Netherlands. \\ 2) Netherlands Institute for Metals Research, also at Laboratory for Materials Science, Delft University of Technology, $2628 \mathrm{AL}$ \\ Delft, the Netherlands.
}

(Received on October 21, 2002; accepted in final form on March 8, 2003)

\begin{abstract}
The Influence of intercritical deformation, cooling rate and prior austenite grain size on bainite formation were investigated by dilatometry tests. Intercritical deformation (0-40\%) performed in steels with a prior austenite grain size of $15-28 \mu \mathrm{m}$ leads to formation of more ferrite during the cooling and less bainite during the subsequent isothermal stage, and even almost no bainite is formed after $40 \%$ strain. Fast cooling after deformation can suppress ferrite transformation. Relaxation following deformation can significantly, but not completely, reduce such effect of deformation due to the occurrence of recovery and recrystallization, particularly for the finer prior austenite grain size. When the prior austenite grain size was changed from 26.8 to $16.8 \mu \mathrm{m}$, bainite formation was suppressed. The mechanism for influence of deformation on bainite formation was discussed on the basis that deformation could refine the austenitic microstructure. Further, it is suggested that there is a critical size of austenite grains or subunits after deformation for the formation of bainite.
\end{abstract}

KEY WORDS: TRIP steels; bainite formation; intercritical deformation; austenite grain size; cooling rate; relaxation.

\section{Introduction}

TRIP-assisted steels usually have high strength and enhanced formability due to the mechanically-induced martensitic transformation of metastable austenite. ${ }^{1)}$ The bainitic transformation of intercritical austenite is of great importance in the processing of TRIP steels since bainite formation allows carbon enrichment of a substantial amount of austenite, which can be subsequently retained after quenching to room temperature for the aim of so-called TRIP effect.

The effect of deformation performed in the austenitic region on the bainite formation has been recently investigated by Bhadeshia and his co-workers. ${ }^{2-5)}$ They concluded that bainite formation from deformed austenite was initially accelerated, but gradually retarded, eventually leading to a smaller fraction of bainite. Furthermore, a larger deformation could lead to a more obvious suppression of bainite formation, which is also called mechanical stabilization. ${ }^{2-5)}$ However, little work on the influence of intercritical deformation, i.e. deformation performed in the austenite plus ferrite dual phase region, has been done. Basuki and Aernoudt ${ }^{6,7)}$ found that intercritical rolling results in an acceleration of ferrite formation and suppression of bainite formation, and refined the retained austenite grains. They suggested that deformation bands, formed during the deformation, divided the austenite grains and effectively refined the retained austenite grains. However, a systematic investigation for a better understanding of influence of intercritical deformation on bainite formation is still lacking. Further, it is difficult to explain why austenitic deformation can accelerate the bainite formation but finally lead to formation of less bainite. ${ }^{3)}$ In the present paper, the influence of intercritical deformation on bainite formation has been further investigated by dilatometry tests. Moreover, influences of relaxation following deformation, cooling rate and prior austenite grain size on bainite formation have been also studied systematically. Finally, a mechanism for the observed influence of deformation on bainite transformation was discussed.

\section{Experiments}

The composition of Al-bearing TRIP steel studied here is $0.19 \% \mathrm{C}-0.27 \% \mathrm{Si}-1.56 \% \mathrm{Mn}-0.012 \% \mathrm{P}-0.57 \% \mathrm{Al}$ (mass percentages). Cylindrical specimens, taken from hot-rolled material and machined to $\phi 5 \mathrm{~mm} \times 10 \mathrm{~mm}$, were used in this investigation. Dilatometry experiments were performed in a Bähr 805 dilatometer. The thermomechanic process used in the present experiments is shown in Fig. 1, which includes three parts. Specimens were firstly heated to different austenitic solution temperatures $\left(950\right.$ and $\left.1100^{\circ} \mathrm{C}\right)$ for $10 \mathrm{~min}$; then cooled to $740^{\circ} \mathrm{C}$ in the intercritical region and deformed to various levels ( $\varepsilon=0,0.2$ and 0.4 ) and followed 


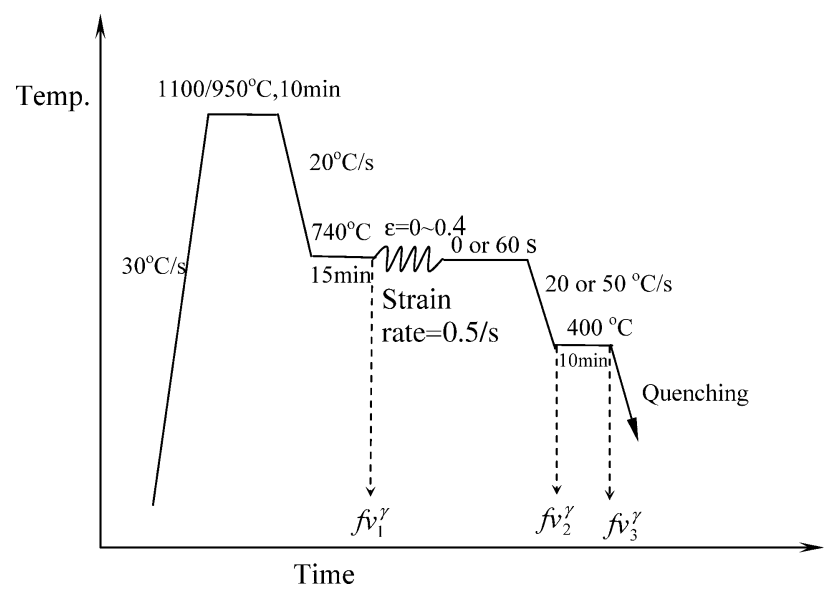

Fig. 1. Thermomechanical process employed in dilatometry experiments.

by relaxation for either 0 or $60 \mathrm{~s}$; next, cooled to the bainitic stage $\left(400^{\circ} \mathrm{C}\right)$ at 20 or $50^{\circ} \mathrm{C} / \mathrm{s}$ and held for $10 \mathrm{~min}$. Finally, they were quenched to room temperature by helium gas.

The quenched samples were cut through cross-sections in the middle of deformed samples, and polished as normal, then etched with $5 \%$ nital and rinsed with water followed by etching in a $10 \%$ sodium metabisulphite solution. This etching is intended to better distinguish between upper bainite and ferrite for quantification of phase fractions because both of them will appear as a light color under the optical microscope after nital etching. Contrastively, such etching can reveal ferrite as light gray, bainite/martensite as black and retained austenite (if preserved) as white. ${ }^{6,7)}$ In addition, nital and saturated picric acid were also used to reveal the prior austenite grain boundaries and ferrite subgrain boundaries. Image analysis software of Leica was used to quantify the volume fractions of ferrite in the quenched specimens and austenite grain sizes achieved from the solution at 950 and $1100^{\circ} \mathrm{C}$. There are three points in the process at which austenite fractions is determined to follow transformations taking place during the whole process, as shown in Fig. 1. Intercritical austenite fraction before the deformation, i.e. $f v_{1}^{\gamma}$, is derived from the optical measurement of the ferrite fractions of interruptedly quenched samples. Similarly, the austenite fraction before bainite formation, i.e. $f v_{2}^{\gamma}$ in Fig.1, is also calculated from the measurements on the ferrite fractions of samples after the whole processing. The remained austenite fraction just after bainite formation, i.e. $f v_{3}^{\gamma}$, is calculated from the dilation signals which will be discussed later. X-ray diffractometry is used to measure the quantity of retained austenite in some quenched specimens after various intercritical deformations, but no clear austenite peaks were detected, suggesting that the residual austenite almost completely transformed to martensite during the quenching after bainite formation, and the final microstructure only consists of ferrite, bainite and martensite.

\section{Results}

\subsection{Influence of Strain and Subsequent Relaxation}

Dilatation data on ferrite and bainite formation resulting from cooling and isothermal treatment respectively are
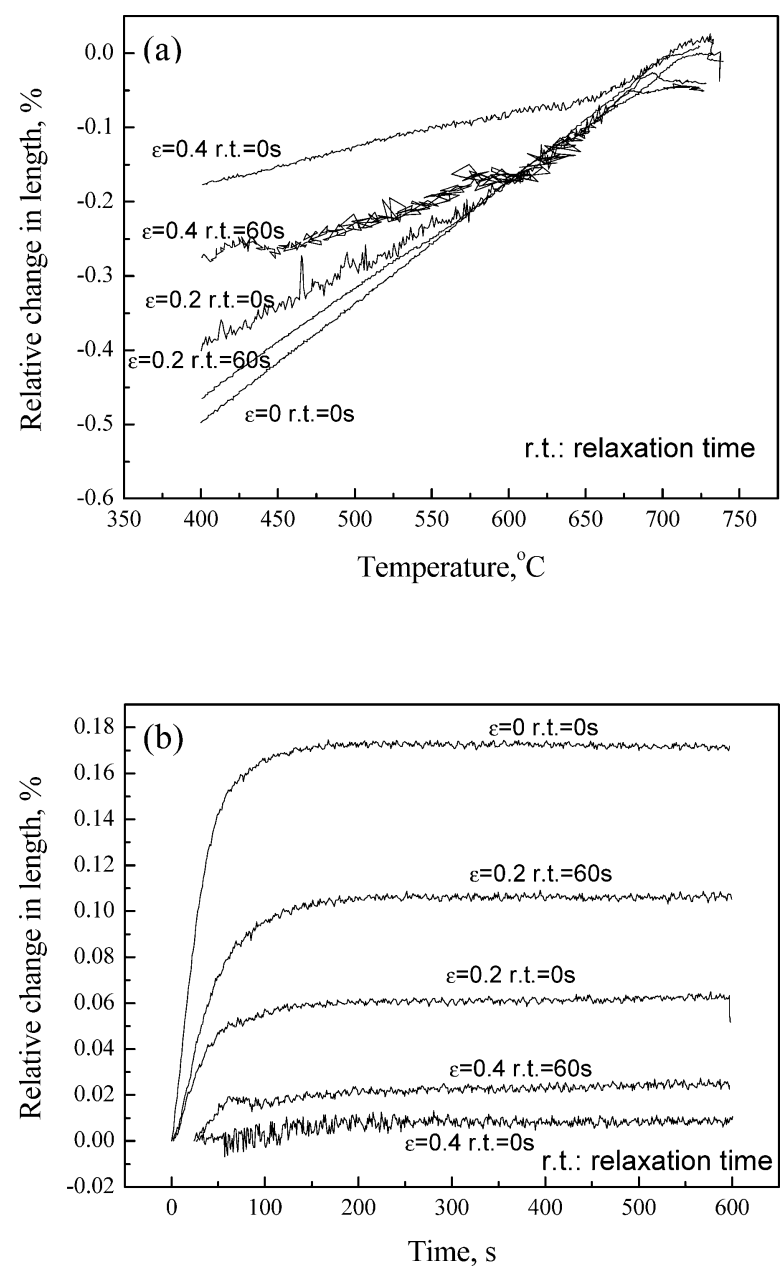

Fig. 2. Influence of intercritical deformation and/or the subsequent isothermal relaxation at $740^{\circ} \mathrm{C}$ on transformations occurring during the cooling from 740 to $400^{\circ} \mathrm{C}$ (a) and isothermal bainitic treatment at $400^{\circ} \mathrm{C}$ (b), revealed by dilatation measurements in the case of austenitic solution temperature at $1100^{\circ} \mathrm{C}$

given in Fig. 2. It has to be mentioned that some of curves of the relative change in length $v s$. temperature in Fig. 2 (and later figures) were moved along the ordinate for the easy comparison. In addition, fluctuation in the signals of dilatation at the beginning of cooling or isothermal holding in the process were ignored, as this is most likely related to temperature fluctuations, resulting from heat in the quartz anvils transferring to the specimen during the cooling and taking some time to build the stable temperature profile in specimens. It is clear from Fig. 2 that intercritical deformation leads to an enhanced transformation during the cooling and suppresses bainite transformation during the subsequent bainitic treatment, assuming that dilation is indicative of a change in phase volume fractions. A larger strain performed in the intercritical region leads to a more transformation during the cooling, and then a less one during the subsequent isothermal stage. It is noted that deformation up to $40 \%$ leads to the formation of very small amount of bainite and an incubation time for bainite formation up to about 25 s. In Fig. 2(b), it is reasonably expected that bainite forms when dilatation starts to increase. The starting points for dilatation to increase during the bainitic treatment were set as zero change in length, and the data before 

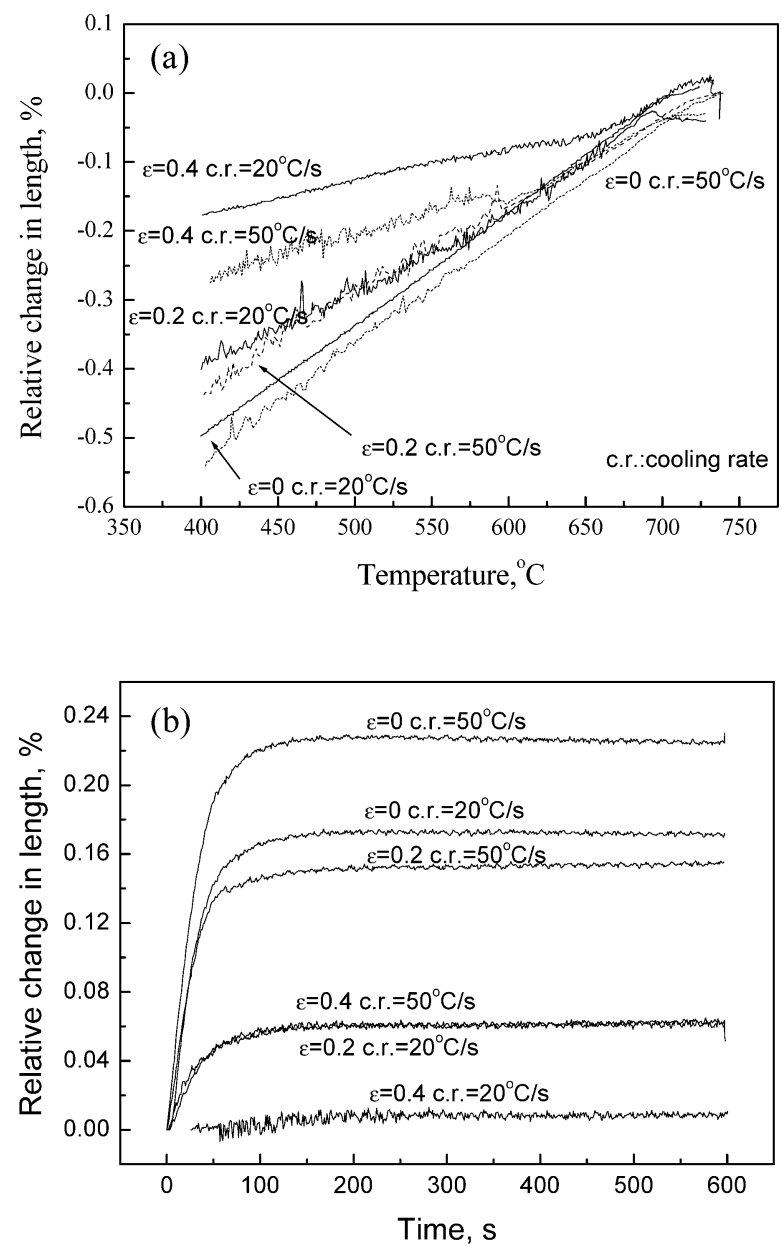

Fig. 3. Influence of cooling rate on transformation of intercritically deformed austenite during the cooling from 740 to $400^{\circ} \mathrm{C}$ (a) and the isothermal stage at $400^{\circ} \mathrm{C}$ for bainitic treatment (b), revealed by dilatation measurements in the case of austenitic solution temperature at $1100^{\circ} \mathrm{C}$.

the starting points were ignored as they result from temperature fluctuations. Relaxation for $60 \mathrm{~s}$ following intercritical deformation does significantly reduce the effect of strain but not completely. That is, with the relaxation for $60 \mathrm{~s}$, more intercritical austenite transforms to bainite during the isothermal treatment instead of ferrite during the cooling.

\subsection{Effect of Cooling Rate after the Intercritical De- formation on Transformations}

A faster cooling rate of $50^{\circ} \mathrm{C} / \mathrm{s}$, which is maximum one available in the Bähr 805 dilatometer for the specimens used, was also performed to study its influence. It seems that the faster cooling after the intercritical deformation clearly suppresses the ferrite formation during the cooling and enhances the subsequent bainite formation during the isothermal treatment, as shown in Fig. 3.

It is noted that the dilatation signals suggest no transformation occurring during the cooling in the case of no intercritical deformation, both at 20 and $50^{\circ} \mathrm{C} / \mathrm{s}$; however, fast cooling $\left(50^{\circ} \mathrm{C} / \mathrm{s}\right)$ still led to more dilatation during the bainitic treatment than slow cooling $\left(20^{\circ} \mathrm{C} / \mathrm{s}\right)$. Possibly part of the observed effect is due to a larger temperature gradient along the lengthwise direction of sample in the fast cooling experiment. For example, in the case of tests without intercritical deformation, the sample contracted

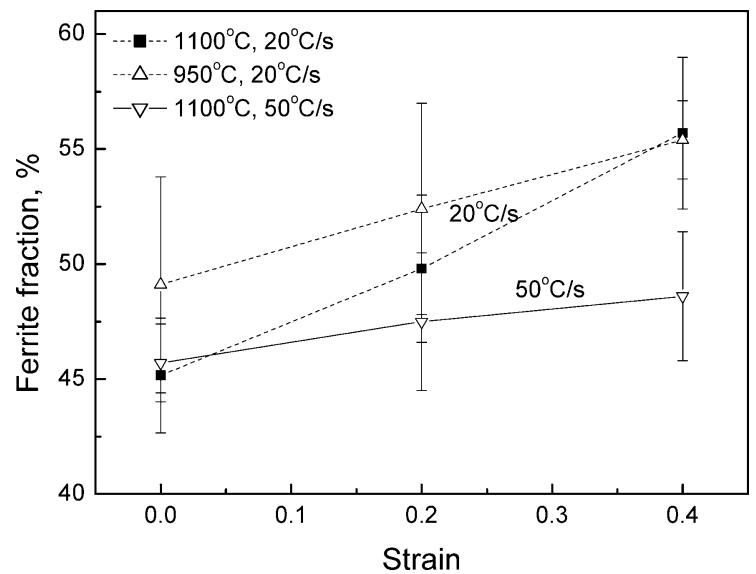

Fig. 4. Ferrite phase fractions measured from the final microstructures in specimens. Error bar indicates the standard deviation of measurements.

$\sim 0.04 \%$ more after cooling from 740 to $400^{\circ} \mathrm{C}$ at $50^{\circ} \mathrm{C} / \mathrm{s}$ than at $20^{\circ} \mathrm{C} / \mathrm{s}$ according to the dilatometry measurements, which is on the same order of magnitude as the dilatation difference of $\sim 0.05 \%$ during the subsequent bainitic treatment (Fig. 3). Therefore, the inherent influence of cooling rate on bainite formation cannot be simply investigated by dilatometry tests.

Metallographic examination was then taken to measure phase fractions of the final microstructures after the entire processing, as given in Fig. 4. These measurements also show that a faster cooling definitely reduces the amount of ferrite formed during the cooling after deformation of $40 \%$.

\subsection{Effect of Austenite Grain Size on Transformations}

The prior austenite grain size resulting from austenitic solution at 1100 and $950^{\circ} \mathrm{C}$ in the process is 26.8 and $14.8 \mu \mathrm{m}$ respectively, which are equivalent diameters and derived by assuming the circular grains with the same area. Besides metallographic measurements proving that intercritical deformation enhanced the formation of ferrite during the cooling (Fig. 4), it also seems to indicate that different austenite grain sizes could lead to some difference in phase fractions of the intercritical microstructure which is the starting microstructure for bainite formation, but such difference is not significant and cannot be definitely distinguished as real one resulting from grain size.

The effect of the austenite grain size on bainite formation seems to depend on relaxation after the intercritical deformation. Without relaxation, a smaller austenite grain size results in the formation of less bainite, see Fig. 5, but a difference in ferrite formation resulting from different grain size could not be definitely observed by dilatation data or metallography measurements. This suggests that the austenite grain size does not have a significant influence on the phase fraction in the microstructure after cooling, i.e. $f_{\mathrm{V}_{2}}$. However, in principle, finer grains usually enhance ferrite formation due to the presence of more nucleation sites. Such small influence of austenite grain size on the amount of ferrite is probably because the size difference in our case, 14.8 and $26.8 \mu \mathrm{m}$, is not large and decreases after deformation, which is not enough to lead to a significant difference in ferrite amount formed after cooling. Contrastively, when specimens were relaxed for $60 \mathrm{~s}$ after defor- 

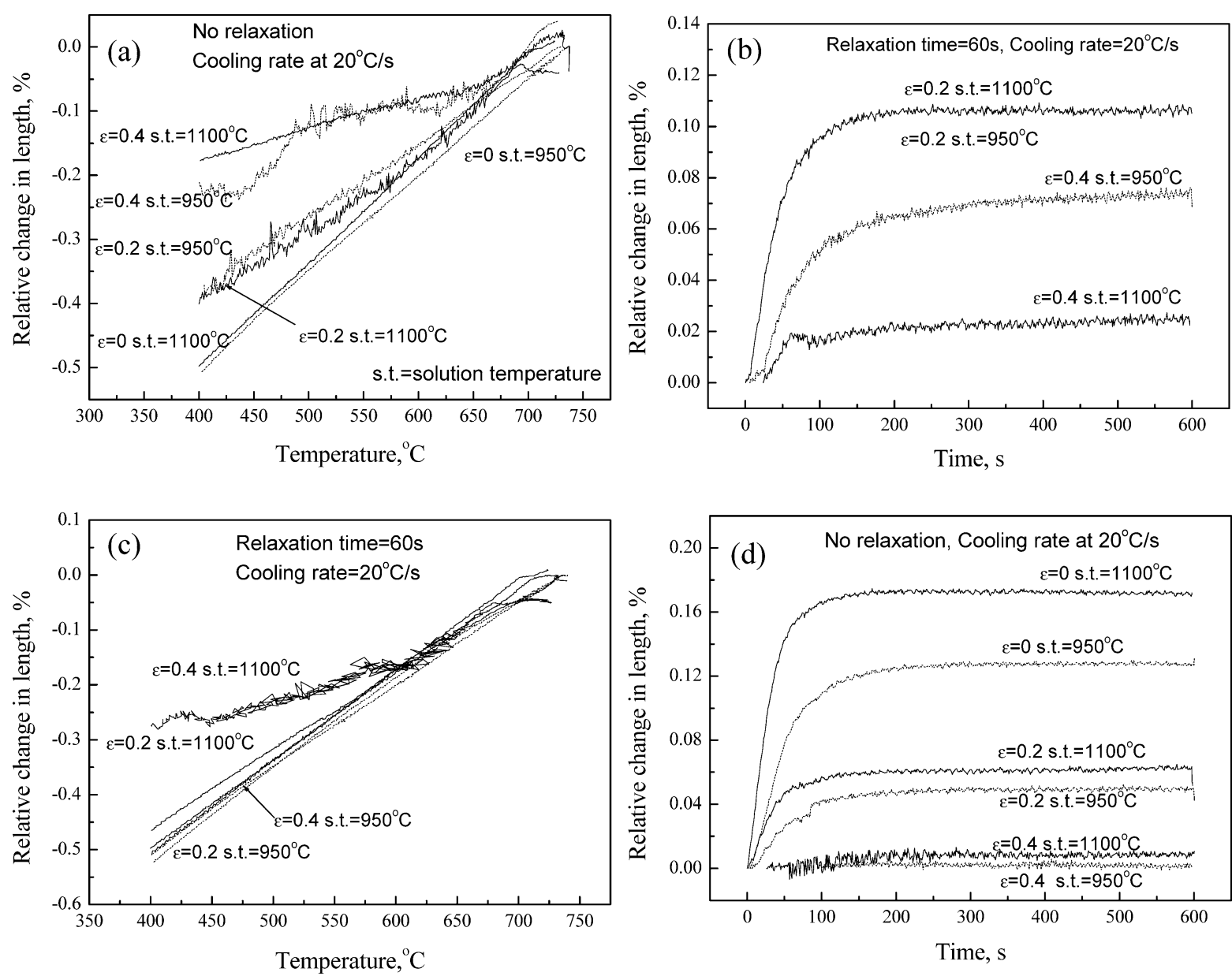

Fig. 5. Influence of austenitic solution temperature on transformation during the cooling from 740 to $400^{\circ} \mathrm{C}$ (a and c) and isothermal stage at $400^{\circ} \mathrm{C}$ for bainitic treatment ( $b$ and d), revealed by dilatation measurements. (a) and (b) in the case of no relaxation following deformation, (c) and (d) in the case of relaxation for $60 \mathrm{~s}$ following deformation.

mation, smaller austenite grain size could lead to less ferrite and more or almost the same amount of bainite formed, as investigated by dilatation and shown in Fig. 5. This indicates that the deformed microstructure is easily recovered and recrystallized in the fine-grain microstructure.

\section{Discussion}

\subsection{Recovery and Recrystallization during Relaxation after the Intercritical Deformation}

Relaxation after intercritical deformation significantly reduced the effect of strain on transformations as stated above, which suggests that recovery or recrystallization should occur in the deformed intercritical austenite grains during the relaxation time. Evolution of microstructures was examined on interruptly quenched specimens and some examples of the microstructure are given in Fig. 6. Nuclei formed in the highly-deformed regions of austenite could grow to new recrystallized grains during the relaxation. Since deformation was performed in the intercritical region, the exact strain in the austenite would be dependent on the austenite phase fraction, phase distribution and total strain. Due to heterogeneity of strain during the uniaxial compression, recrystallization only occurred in some highly deformed regions, for example, in the austenite near austen- ite/ferrite interfaces due to the strain constraint. In other regions, only recovery was possible for softening of materials. It is estimated that holding for $60 \mathrm{~s}$ after deformation might be not enough for the complete recrystallization. Consequently, the deformed microstructure could not be fully recovered to the undeformed state and then suppression of bainite transformation resulting from deformation could not be completely eliminated.

\subsection{Influence of Cooling Rate and Austenite Grain Size on Bainite Formation}

Fast cooling could suppress the austenite-to-ferrite transformation during the cooling due to the less time for the diffusional transformation, leaving more austenite for the following bainite formation; however, fast cooling would help to keep more dislocations introduced by deformation, remaining after cooling, which could suppress bainite formation as discussed above. Therefore, the influence of cooling rate on bainite formation depends on the balance between the two contradictory factors, and is usually insignificant, which might be the reason why dilatation data could not reveal significant differences resulting from the different cooling rates, as mentioned above.

Finer austenite grains size may enhance the ferrite formation during the cooling due to the more nucleation site being available for transformation, which leads to less 


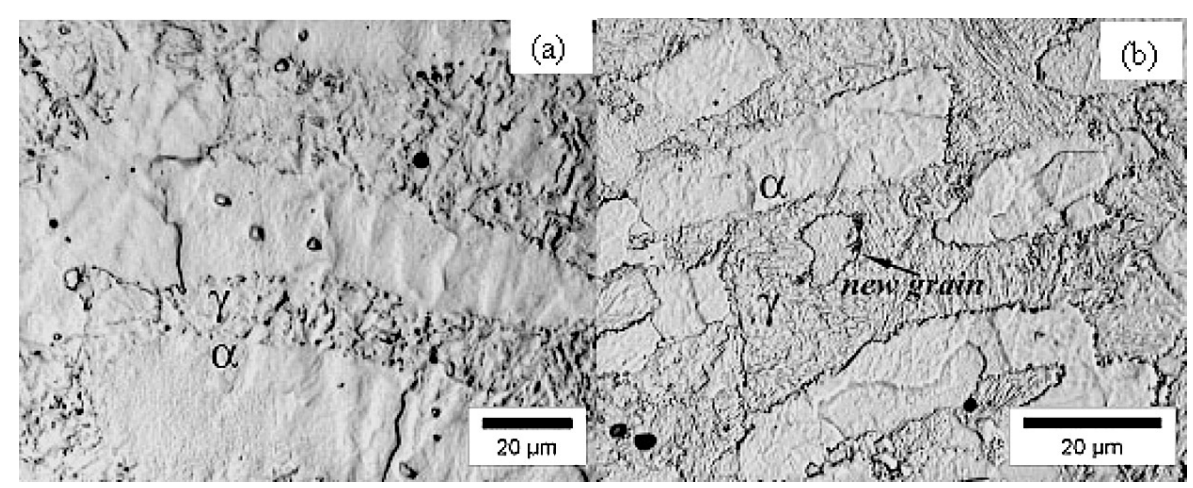

Fig. 6. Recrystallization occurring in the intercritical austenite during relaxation after deformation. (a) Immediately quenched after deformation to $40 \%$ at $740^{\circ} \mathrm{C}$ and (b) relaxed for $60 \mathrm{~s}$ and then quenched after deformation at $740^{\circ} \mathrm{C}$; etched by picric acid.

Table 1. Phase fraction of austenite transformed during the cooling and bainitic treatment, calculated from the metallographic measurements and dilatation respectively.

\begin{tabular}{|c|c|c|c|c|c|c|c|c|}
\hline \multicolumn{4}{|c|}{$\begin{array}{l}\text { Specimens under the different processing } \\
\text { conditions }\end{array}$} & \multirow{2}{*}{$\begin{array}{c}f v_{1}^{\gamma} \\
\%\end{array}$} & \multirow{2}{*}{$\begin{array}{c}f v_{2}^{\gamma} \\
\%\end{array}$} & \multirow{2}{*}{$\begin{array}{c}f v_{3}^{\gamma} \\
\%\end{array}$} & \multirow{2}{*}{$\begin{array}{c}\text { Ferrite } \\
\text { fraction } \\
\% \\
\%\end{array}$} & \multirow{2}{*}{$\begin{array}{c}\text { Bainite } \\
\text { fraction } \\
\quad \%\end{array}$} \\
\hline \multirow{6}{*}{$\begin{array}{l}\text { Austenitic } \\
\text { Solution } \\
\text { temperature } \\
=1100^{\circ} \mathrm{C}\end{array}$} & Strain & $\begin{array}{l}\text { Relaxation } \\
\text { time }\end{array}$ & $\begin{array}{c}\text { Cooling } \\
\text { rate }\end{array}$ & & & & & \\
\hline & 0 & $0 \mathrm{~s}$ & $20^{\circ} \mathrm{C} / \mathrm{s}$ & 54.8 & 54.8 & 31.5 & 0 & 23.3 \\
\hline & 0.2 & $0 \mathrm{~s}$ & $20^{\circ} \mathrm{C} / \mathrm{s}$ & 54.8 & 50.2 & 41.9 & 4.6 & 8.3 \\
\hline & 0.4 & $0 \mathrm{~s}$ & $20^{\circ} \mathrm{C} / \mathrm{s}$ & 54.8 & 44.3 & 43 & 10.5 & 1.3 \\
\hline & 0.2 & $60 \mathrm{~s}$ & $20^{\circ} \mathrm{C} / \mathrm{s}$ & 54.8 & 51.8 & 38.5 & 3.0 & 3.3 \\
\hline & 0.4 & $60 \mathrm{~s}$ & $20^{\circ} \mathrm{C} / \mathrm{s}$ & 54.8 & 48.4 & 45.1 & 6.4 & 3.3 \\
\hline \multirow{5}{*}{$\begin{array}{l}\text { Austenitic } \\
\text { Solution } \\
\text { temperature } \\
=950^{\circ} \mathrm{C}\end{array}$} & 0 & $0 \mathrm{~s}$ & $20^{\circ} \mathrm{C} / \mathrm{s}$ & 50.8 & 50.8 & 34 & 0 & 16.8 \\
\hline & 0.2 & $0 \mathrm{~s}$ & $20^{\circ} \mathrm{C} / \mathrm{s}$ & 50.8 & 47.6 & 41 & 3.2 & 5.6 \\
\hline & 0.4 & $0 \mathrm{~s}$ & $20^{\circ} \mathrm{C} / \mathrm{s}$ & 50.8 & 44.6 & 44.2 & 6.2 & 0.4 \\
\hline & 0.2 & $60 \mathrm{~s}$ & $20^{\circ} \mathrm{C} / \mathrm{s}$ & 50.8 & 48.5 & 34.4 & 2.3 & 14.1 \\
\hline & 0.4 & $60 \mathrm{~s}$ & $20^{\circ} \mathrm{C} / \mathrm{s}$ & 50.8 & 47.3 & 37.4 & 3.5 & 9.9 \\
\hline \multirow{4}{*}{$\begin{array}{l}\text { Austenitic } \\
\text { Solution } \\
\text { temperature } \\
=1100^{\circ} \mathrm{C}\end{array}$} & 0 & $0 \mathrm{~s}$ & $50^{\circ} \mathrm{C} / \mathrm{s}$ & 54.3 & 54.3 & 24.6 & 0 & 29.7 \\
\hline & 0.1 & $0 \mathrm{~s}$ & $50^{\circ} \mathrm{C} / \mathrm{s}$ & 54.3 & 54.3 & 27.4 & 0 & 26.9 \\
\hline & 0.2 & $0 \mathrm{~s}$ & $50^{\circ} \mathrm{C} / \mathrm{s}$ & 54.3 & 52.5 & 34.6 & 1.8 & 17.9 \\
\hline & 0.4 & $0 \mathrm{~s}$ & $50^{\circ} \mathrm{C} / \mathrm{s}$ & 54.3 & 51.4 & 43.3 & 2.9 & 8.1 \\
\hline
\end{tabular}

$f v_{1}^{\gamma}$ : Calculated from microscopic measurements on ferrite phase fractions in specimen without intercritical deformation and assumed as the intercritical austenite fraction before deformation for other specimens in the same class as shown in Fig.1

$f v_{2}^{\gamma}$ : Calculated from microscopic measurements on ferrite phase fractions in specimens after complete processing and assumed as the austenite fraction just before bainite transformation, as shown in Fig.1.

$f v_{3}^{\gamma}$ : Calculated from dilatation data during the bainite forming stage and assumed as the austenite fraction just after the formation of bainite, as shown in Fig.1.

${ }^{1}$ Ferrite fraction: the fraction of ferrite formed during the cooling and equal to $f v_{1}^{\gamma}-f v_{2}^{\gamma}$

${ }^{2}$ Bainite fraction $=f v_{2}^{\gamma}-f v_{3}^{\gamma}$

austenite for the following bainite formation. Besides this, it seems that smaller grain size itself also has some influence on bainite formation. However, conflicting results on influences of austenite grain size were reported in literature. Davenport ${ }^{8)}$ found that austenite grain size had no appreciable effect on the transformation kinetics. A deceleration of the bainite formation rate due to the increasing austenite size was reported by Barford and Owen, ${ }^{9)}$ who discovered that increasing in the time for the formation to $25 \%$ bainite is directly proportional to the grain diameter. By contrast, Graham and Axon ${ }^{10)}$ suggested that a smaller grain size should retard bainite plate growth because the growth of a bainite plate is resisted by the matrix.

In order to clarify this inherent influence of grain size in our investigation, dilatation data need be converted to phase fractions on the basis of metallographic measurements. As ferrite should form during the cooling, the ferrite phase fractions in the final microstructures after complete processing have been measured and then changed to austenite
Table 2. Effect of temperature $\left(T,{ }^{\circ} \mathrm{C}\right)$ and carbon concentration ( $w_{\mathrm{C}}$, only for austenite, $\left.\mathrm{wt} \%\right)$ on the lattice parameters of ferrite and austenite $(a, \AA){ }^{12)}$

\begin{tabular}{|l|l|}
\hline Phase & Relation \\
\hline Austenite & $\begin{array}{l}a_{\gamma}=\left(3.6306+7.8 \times 10^{-3} \times \xi\right)\left[1+(24.9-0.51 \times \xi) \times 10^{-6} \times(T-727)\right] \\
\text { where } \xi=4.650 \times w_{C} /\left(3.650 \times w_{C}+100\right)\end{array}$ \\
\hline Ferrite & $a_{\alpha}=2.8863\left[1+17.5 \times 10^{-6} \times(T-527)\right]$ \\
\hline
\end{tabular}

fraction remained after cooling for bainite formation, as given in Table 1. These were used to calibrate the austenite phase fraction transformed during the cooling. However, it is difficult to directly measure bainite phase fraction due to similarity between bainite and martensite, and therefore bainite phase fraction was calculated from dilatometry data by following the calculation as described in Ref. 11). The lattice parameters used are shown in Table 2. It needs to be mentioned that the scaling factor of $k=1$ (in Eq. (2) of Ref. 11) was used in the calculations since the relative change in 

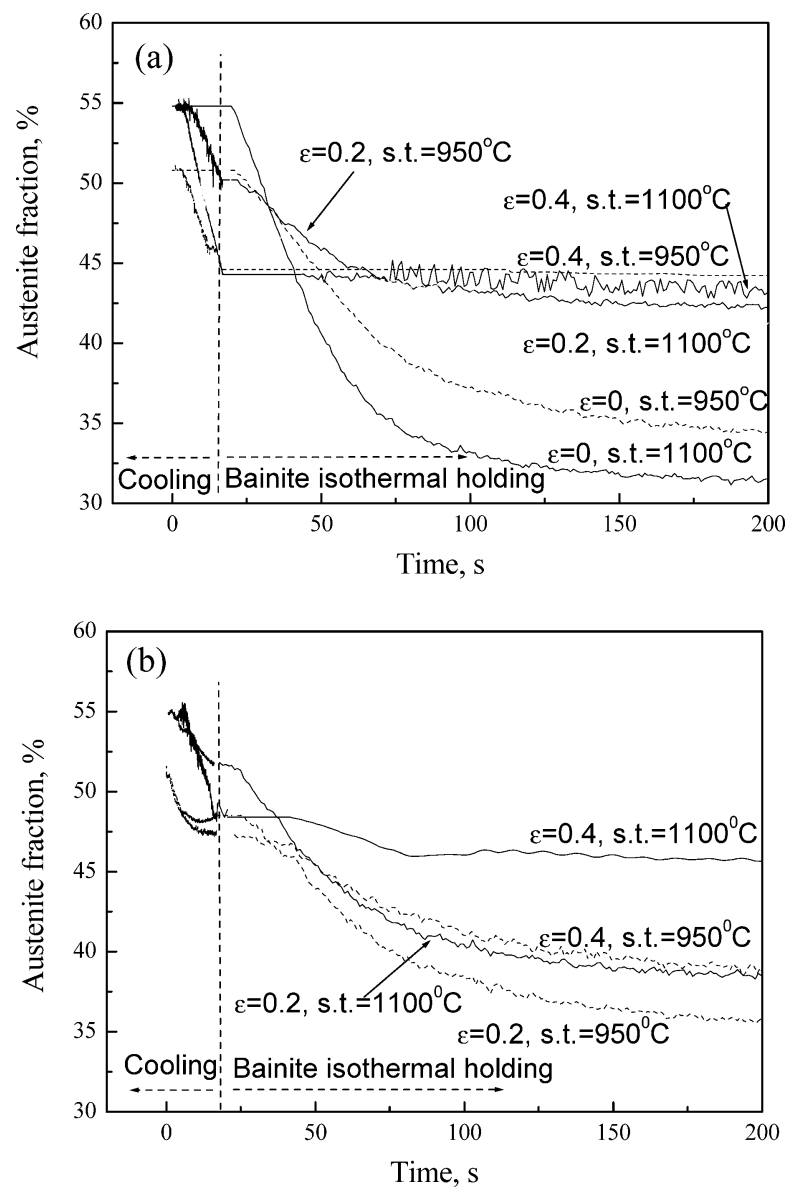

Fig. 7. Austenite fraction transformed during the cooling from 740 to $400^{\circ} \mathrm{C}$ and the following isothermal stage at $400^{\circ} \mathrm{C}$ for bainitic treatment. (a) No relaxation after deformation and (b) relaxation for $60 \mathrm{~s}$ after deformation.

length at the starting point of bainite formation was set to zero. Since this scaling factor is usually very close but not equal to 1 in practice, ${ }^{13}$ this could result in some inaccuracy of the calculated results. In this investigation, however, what we need is the relative difference made by the different processing in order to know the influence of processing parameters (strain, cooling rate and grain size). On the assumption that dilation data could reflect the change in volume phase fraction in the same way for each processing, using $k=1$ in calculations for all kinds of processing can ensure that phase fractions calculated from dilation data are comparable. The austenite phase fractions transformed during both cooling and isothermal stage are shown in Fig. 7 and exact data are given in Table 1 . However, it has to be mentioned once again that comparison of amounts of bainite formed should be based on the same cooling rate since cooling rate may also affect the dilatation of samples during the bainitic treatment as discussed before.

It was noted that the remained austenite after bainite formation was around $32-47 \%$ (Fig. 7), corresponding to a $0.40-0.59 \% \mathrm{C}$ (mass) carbon concentration enrichment in austenite. Stability of the remained austenite can be evaluated by Wang's equation ${ }^{14)}: M_{\mathrm{s}}=273+545.8 \cdot e^{-1.362 w_{\mathrm{C}}}$ (in degrees centigrade), where $w_{\mathrm{C}}$ is the mass percentage of carbon and $M_{\mathrm{s}}$ is the martensite-start temperature. Such enriched carbon concentration corresponds to martensite transformation points around $244-316^{\circ} \mathrm{C}$, which is much higher than room temperature. This explained why all residue austenite transformed to martensite during the quenching and no retained austenite was detected in the quenched specimens.

In the case of no deformation, the bainite fraction formed from austenite is $23.3 \%$ at the solution temperature of $1100^{\circ} \mathrm{C}$ and $16.8 \%$ at $950^{\circ} \mathrm{C}$, i.e. about $7 \%$ difference between bainite phase fractions in both processes. It is noted that the starting microstructure for bainite formation might be also different. The possible difference in austenite fraction was estimated to be around $4 \%$ according to the metallographic measurements. After contribution from the possible $4 \%$ less austenite in the finer-grain specimen was subtracted from the total difference of $7 \%$ in bainite fraction, there was still around $3 \%$ more bainite in specimen with smaller grain size, which should result from the inherent influence of different austenite grain size. That is, the smaller grain size itself suppressed the bainite formation even if it did not lead to less austenite remaining after the cooling. This is also consistent with Graham and Axon's suggestion $^{10)}$ that a smaller grain size should retard the growth of bainite due to the matrix constraint. In addition, this suppression resulting from the smaller grain size tended to decrease after deformation. However, if recovery or recrystallization happened after deformation, the smaller grain size could enhance such softening and lead to more bainite formed (Fig. 7(b)) as discussed before.

\subsection{Mechanism for Influence of Intercritical De- formation on Bainite Transformation}

One reason why intercritical deformation could suppress bainite formation is that intercritical deformation causes enrichment of carbon in austenite by formation of more ferrite and then enhances the stability of remained austenite against bainite formation. However, the carbon concentration increased only a little, from 0.40 to $0.59 \%$ after $40 \%$ deformation, which cannot make a significant contribution on suppression of bainite formation resulting from deformation. Bhadeshia ${ }^{2,3)}$ and Singh ${ }^{4}$ observed that deformed austenite usually transformed to bainite faster at the beginning than undeformed austenite, then this transformation was gradually retarded until a smaller final fraction of bainite. They supposed that plastic deformation of austenite prior to its transformation produced deformation debris to hinder the growth of bainite, similar to its influence on the typical displacive transformation of martensite in spite of an increased density of nucleation sites. Further, non-homogeneity of strain in the uniaxially compressed specimens was used to explain the initial acceleration of transformation but the smaller final fraction. By their theory, however, it is difficult to understand why a severe deformation can almost completely suppress the formation of bainite as shown in Figs. 2 and 3. How can a large deformation strongly enhance the nucleation of bainite formation but at the same time lead to almost no bainite formed? Bhadeshia and Singh's theory ${ }^{2-4)}$ seems clearly not convincing unless it is assumed that no bainite can form in the highly deformed area. Basuki and Aernoudt ${ }^{6,7)}$ suggested that deformation bands formed during the simulated intercritical rolling divided the austenite grains into several parts, which suppressed the bainite growth since bainite is only allowed to 


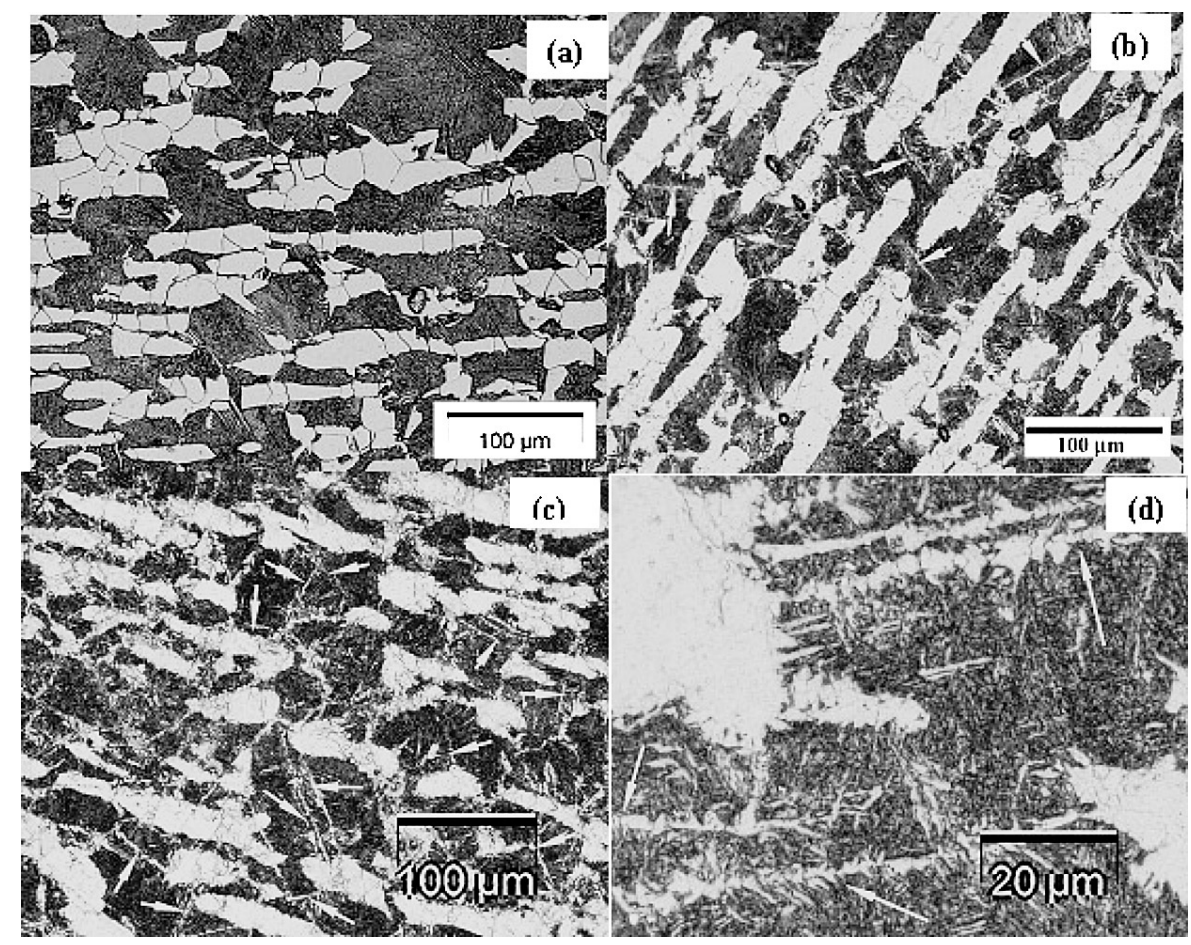

Fig. 8. Intercritical deformation resulted in deformation bands (indicated by arrows) in austenite, which then transformed to ferrite and divided austenite grains into several parts. Specimens were deformed to (a) 0 , (b) $20 \%$, (c) and (d) $40 \%$ and then directly cooled to $400^{\circ} \mathrm{C}$ at $20^{\circ} \mathrm{C} / \mathrm{s}$ for bainite formation.

grow within austenite. But they seemed to lack the clear experimental proof for deformation bands. In our work, optical observation has been able to give definite proof for this viewpoint. Deformation bands formed in austenite during the intercritical deformation acted as nucleation sites, which transformed to ferrite during the cooling, as shown in Fig. 8. This is consistent with many research results which have been published. Kojima and his co-workers ${ }^{15}$ ) found that the deformation bands produced by large reduction in non-recrystallization temperature region of austenite acted as nucleation sites for ferrite formation and finally refine the ferrite grains. Hurely et al. ${ }^{16,17)}$ further presented more direct evidence by using a model austenitic $\mathrm{Fe}-$ $30 \% \mathrm{Ni}$ alloy in which the preferred sites for intragranular ferrite nucleation are microbands produced in the austenitic deformation. The ferrite nucleated to form parallel and closely spaced arrays within one prior austenite grain. By using the similar model alloy, Adatchi et al. ${ }^{18)}$ made the more detailed observation that deformation substructure are microbands below $700^{\circ} \mathrm{C}$ whilst equiaxed dislocation cell structures above $800^{\circ} \mathrm{C}$. All of these previous researches support that austenitic deformation may produce such deformation microstructures as microbands and dislocation cells. In our experiments, these bands in austenite produced by intercritical deformation would transform to ferrite which straightly crossed the austenite grains and divided austenite grains into several parts. Furthermore, a larger deformation could lead to more deformation bands within austenite grains and more ferrite fragments (Fig. 8). In addition, the initial transformation rate could increase apparently with the decreasing strain, as shown in Fig. 9, which was plotted by following the same calculations as for Fig. 7 . This is different from influence of austenitic deformation as Singh and Bhadeshia ${ }^{2-4)}$ reported that austenitic deforma-

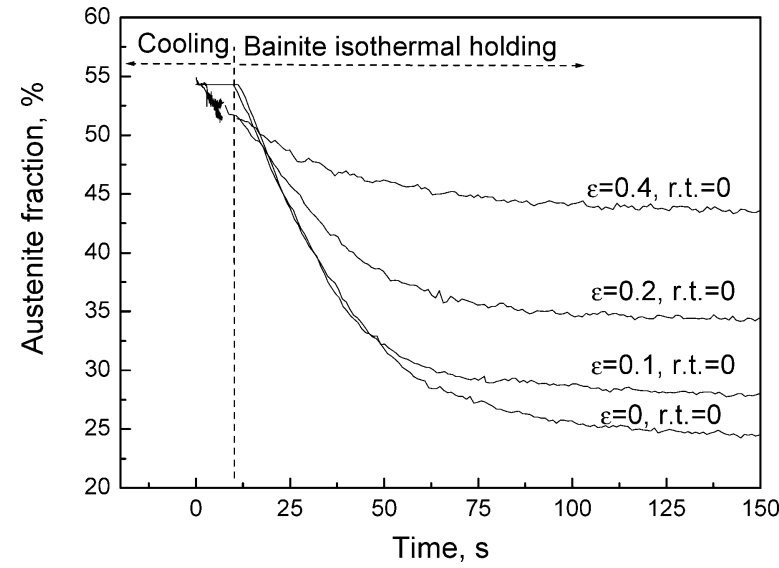

Fig. 9. Austenite fraction transformed during the cooling from 740 to $400^{\circ} \mathrm{C}$ at the cooling rate of $50^{\circ} \mathrm{C} / \mathrm{s}$ and the following isothermal stage at $400^{\circ} \mathrm{C}$ for bainitic treatment.

tion accelerated the initial bainite transformation rate. Obviously, one reason for this conflict is that some of the additional nucleation sites produced by deformation have been consumed by the formation of ferrite before bainite formation in our case. Smaller strain leads to a less deformed microstructure, which is easier to keep for bainite formation, particularly after fast cooling as austenite-to-ferrite formation is suppressed. For example, cooling at the rate of $50^{\circ} \mathrm{C} / \mathrm{s}$ completely suppressed ferrite formation during the cooling after $10 \%$ deformation, and then the subsequent bainite transformation rate shows a slight acceleration at the beginning compared with the undeformed one.

After deformation bands formed within austenite grains and then transformed to ferrite, bainite was only allowed to form between these bands with a smaller size, thus, growth of bainite was suppressed. This, however, is not enough to 
explain the complete suppression in the case of large deformation. It seems that bainite cannot form at all when deformation is more than a certain value. It has been stated that a higher strain could lead to more deformation bands, which divided the austenite grains into more smaller parts. These subunits were usually separated by deformation bands or debris, which could not be crossed by the bainite growth as bainite formation is a displacive transformation. ${ }^{2-4)}$ From this viewpoint, deformation has a similar mechanism to affect displacive transformation as grain size, as deformation also divides the austenite grains into smaller subunits, which can affect the invariant-plane transformation in two ways. One is to increase the nucleation sites in favour of bainite formation with increasing strain or decreasing grain size. The other is retarding of bainite formation because of refinement of microstructures due to formation of subunits in austenite grains after deformation. It has been reported that smaller austenite size helps the retention of austenite instead of martensite formation. ${ }^{19-21)}$ Since bainite formation has the characteristic of invariant-plane displacive transformation like martensite, bainite might not form when the parent phase is refined to a certain degree due to the matrix constraint. It is supposed that there is a critical grain (or subunit) size below which formation of bainite will be prevented. Entwisle ${ }^{22)}$ and Magee $^{23)}$ reported that kinetics of isothermally formed martensite depends largely on the grain size when it is down to $20 \mu \mathrm{m}$, and Wang et $a l .{ }^{14)}$ thought that nucleus density required by an athermal nucleation mechanism could be achieved only when the dispersed austenite grain size is as small as $1 \mu \mathrm{m}$. Adachi et $a l .{ }^{18)}$ even presented experimental evidence that the sizes of dislocation cells produced by austenitic deformation above $800^{\circ} \mathrm{C}$ were around $1 \mu \mathrm{m}$. The prior austenite grain size ranges from 15 to $28 \mu \mathrm{m}$ in our investigation, thus, it could be estimated that this critical size is at least less than 10 $\mu \mathrm{m}$, most likely in the scale of a few micrometers or even smaller, since the prior austenite grain sizes of industrial TRIP steels are usually quite fine. It was noted that the prior austenite grain size is around $135 \mu \mathrm{m}$ and the maximum strain is 0.69 in Singh's work, ${ }^{4)}$ which is much coarser than that in our investigation. Thus, it could be possible that most of austenite subunits after deformation in a coarsegrained structure are still larger than the critical one and still able to transform to bainite, then transformation is initially accelerated due to the increased nucleation sites. However, it would stop at the smaller final fraction of bainite because deformation also refined the residual austenite and enhanced its retention against the further bainite formation. Contrastively, the prior austenite grains are quite finer in our case, around 15-28 $\mu \mathrm{m}$, thus, the microstructures could be easily refined to less than the critical size by deformation, and then bainite formation could be almost completely suppressed. This also explains why influence of austenite size on bainite transformation becomes weaker after intercritical deformation (Figs. 5(a) and 5(b)) because the size difference resulting from the different solution temperatures would reduce after deformation. This idea suggests that formation of bainite should be similar to martensite instead of ferrite, which is always enhanced by prior deformation, and even bainite nucleation should be displacive.
This theory based on the critical austenite size for bainite formation also gives some possibilities to explain the conflicting results on influence of austenite grain size on bainite formation. As the prior austenite grain sizes and heating treatment are usually different in various investigations, the finally achieved subunit size in austenite could be either more or less than the critical size for bainite formation, consequently, acceleration or deceleration on bainite formation could be observed in the different conditions.

\section{Conclusions}

Influences of intercritical deformation, cooling rate and prior austenite grain size on bainite formation were investigated by the dilatometry tests; some conclusions could be drawn as follows:

(1) Intercritical deformation performed in steels with the prior austenite size of $15-28 \mu \mathrm{m}$ apparently leads to formation of more ferrite during the cooling and less bainite during the subsequent isothermal stage, and even almost no bainite is formed after $40 \%$ strain. It can also result in formation of deformation bands across the austenite grains, on which ferrite is formed during the cooling. These bands divided the austenite grains into relatively small parts, which may prevent the growth of bainite.

(2) Relaxation after deformation could significantly, but not completely, eliminate such effect of deformation due to the occurrence of recovery and recrystallization, particularly in the smaller-grained microstructure because there are more nucleation sites available for recrystallization.

(3) Faster cooling could suppress the ferrite formation during the cooling, leaving more austenite for bainite formation; meanwhile keep more dislocations in the microstructure against bainite formation. Therefore its influence on bainite formation is not so significant.

(4) When prior austenite grain size changed from 26.8 to $16.8 \mu \mathrm{m}$, bainite formation was suppressed, presumably resulting from a severer matrix constraint.

(5) It is supposed that there exists a critical size of austenite grains or subunits within grains after deformation for the formation of bainite, below which bainite cannot form. Influence of deformation is then dependent on whether the size of final austenite grains or subunits achieved by deformation is more than the critical one or not. When the prior austenite grains are quite fine, a severe deformation could lead to subunits after deformation smaller than critical size, and then a complete suppression on bainite transformation without any acceleration. Contrarily, if the prior grains are rather coarse and subunits after deformation are still more than critical size, deformation could accelerate bainite formation due to the increased density of nucleation sites.

\section{REFERENCES}

1) P. Jacques, E Girault, T. Catlin, N. Geerlofs, T. Kop, S. van der Zwaag and F. Delannay: Mater. Sci. Eng., A273-275 (1999), 475.

2) H. K. D. H. Bhadeshia: Bainite in steels, second ed., IOM Communications Ltd., London, (2001), 207.

3) H. K. D. H. Bhadeshia: Mater. Sci. Eng., A273-275 (1999), 58.

4) S. B. Singh: Doctorate Dissertation, University of Cambridge, (1998). 
ISIJ International, Vol. 43 (2003), No. 8

5) P. H. Shipway and H. K. D. H. Bhadeshia: Mater. Sci. Technol., 11 (1995), 1116.

6) A. Basuki and E. Aernoudt: J. Mater. Process. Technol., 89-90 (1999), 37.

7) A. Basuki and E. Aernoudt: Scr. Mater., 40 (1999), 1003.

8) A. S. Davenport: Trans. Metall. Soc. AIME, 145 (1941), 301

9) J. Barnard and W. S. Owen: J. Iron Steel Inst., 197 (1961), 146.

10) L. W. Graham and H. J. Axon: J. Iron Steel Inst., 191 (1959), 361.

11) L. Zhao, T. A. Kop, V. Rolin, J. Sietsma, A. Mertens, P. J. Jacques and S. van der Zwaag: J. Mater. Sci., 37 (2002), 1585.

12) M. Onink, C. M. Brakman, F. D. Tichelaar, E. J. Mittermeijer, S. van der Zwaag, J. H. Root and N. B. Konyer: Scr. Metall. Mater, 29 (1993), 1011.

13) T. Kop: Doctorate Thesis, Delft University of Technology, (2000).

14) J. Wang and S. van der Zwaag: Metall. Mater. Trans. A, 32A (2001), 1527.
15) A. Kojima, Y. Watanabe, Y. Terada, A. Yoshie and H. Tamehiro: ISIJ Int., 36 (1996), 603.

16) P. J. Hurley, B. C. Muddle and P. D. Hodson: Metall. Mater. Trans. A, 33A (2002), 2985.

17) P. J. Hurely, B. C. Muddle, P. D. Hodson, C. H. J. Davies, B.P. Wynne, P. Cizek and M. R. Hickson: Mater. Sci. Forum, 284-286 (1998), 159

18) Y. Adachi, T. Tomida and S. Hinotani: ISIJ Int., 40 (2000), supplement, S194.

19) N. C. Goel, J. P. Chakravarty and K. Tangri: Metall. Trans. A, 18A (1987), 5.

20) P. Ostron, B. Lonnberg and I. Lindgren: Met. Technol., (1981), 81

21) P. Huang and H. F. Lopez: Mater. Sci. Technol., 15 (1999), 157.

22) A. R. Entwisle: Metall. Mater. Trans., 2 (1971), 2395

23) C. L. Magee: Metall. Mater. Trans., 2 (1971), 2419. 